\title{
E-Learning in the School: Applied to Teaching Mathematics in Portugal
}

\author{
Maria João Gonçalves and Claus Kaldeich \\ Escola de Engenharia, University of Minho, Guimarães, Portugal
}

\author{
mjoaogoncalves@gmail.com cka@dsi.uminho.pt
}

\begin{abstract}
In this paper will be present a snapshot of the situation of teaching and learning Mathematics in Portugal, as well as some statistics which pose the reality of this subject in the school rooms and homes of this country. Further will be present some applications of the Information and Communication Technologies (ICT) to improve the teaching and learning activities of Mathematics, in the school room and at home. Some platforms which support the e-learning will be present too, as motivation to apply these technologies in a larger scale in the education in Portugal or in other countries.
\end{abstract}

Keywords: $e$-learning; applied information and communications technologies in the school room; Mathematics; effective teaching and learning

\section{Teaching and Learning Mathematics in Portugal: A Case of Unsuccess}

\section{Mathematics}

Mathematics is an ancient science, which is part of the educational programmes. It has been a compulsory subject since centuries ago and it has also played a role on social selection.

Mathematics' teaching has been, systematically, a target of great concern and debate. However, this happens for the worst reasons, such as the failure registered in the subject and highlighted by the position Portuguese students achieved in international studies.

The problem with Mathematics' unsuccess is not easy to solve and cannot be analysed in a simple way. The truth is, the conception that Mathematics is an extremely difficult subject endures, as well as the idea that only intelligent people are able to understand it. When this kind of thought prevails, a true social phobia to Mathematics begins. "Our schools and our students are still living a certain sense of Mathematics' poor education, which we must try to cease. Mathematics is continuing to be seen as a very difficult subject." (Costa, 2004, p.7).

Material published as part of this publication, either on-line or in print, is copyrighted by the Informing Science Institute.

Permission to make digital or paper copy of part or all of these works for personal or classroom use is granted without fee provided that the copies are not made or distributed for profit or commercial advantage AND that copies 1) bear this notice in full and 2) give the full citation on the first page. It is permissible to abstract these works so long as credit is given. To copy in all other cases or to republish or to post on a server or to redistribute to lists requires specific permission and payment of a fee. Contact Publisher@InformingScience.org to request redistribution permission.
Maths teachers have supported their teaching methods on memorization and repetition of rules and calculus' techniques, giving the students a vision of an abstract science, which is disconnected from the understandable reality. Students also get the idea that to study Maths it is necessary to know a variety of exercises that will enable them to give accurate answers on tests and exams. Thus, students believe Maths is not 
worthy, once most of them consider it to be incomprehensible.

It is imperative to change these ideas. A new perspective of Mathematics should be developed. It is important to observe Mathematics and its learning as a process that help us to understand the concepts constructions connected with the daily life.

\section{The Unsuccess in Mathematics in Portugal}

It is clear that something is wrong with Mathematics teaching. This is proved everyday by the general school failure, and by the lack of interest and motivation for the subject.

"The unsuccess is traduced, not only in unsatisfactory levels of learning, but also in the lack of trust present on the use of mathematical' concepts and techniques, in a general, poor and corrupted vision of this science's nature, and with an attitude of alienation or even of repulse for this subject." (Ponte, 1988, p.10).

The levels of unsuccess in Mathematics are, nowadays, cause of great concern, no matter how you analyse it.

It is clear to see high percentages of students with negative results in Maths. This may be observed in different school years, or in students that start showing indifference for this subject early at school.

In Portugal, Maths presents high unsuccess rates. This means that the majority of students are not able to understand and apply the contents studied in classes. This situation can be easily observed in Figure 1, which depicts the results in the 2005 National Maths Exam.

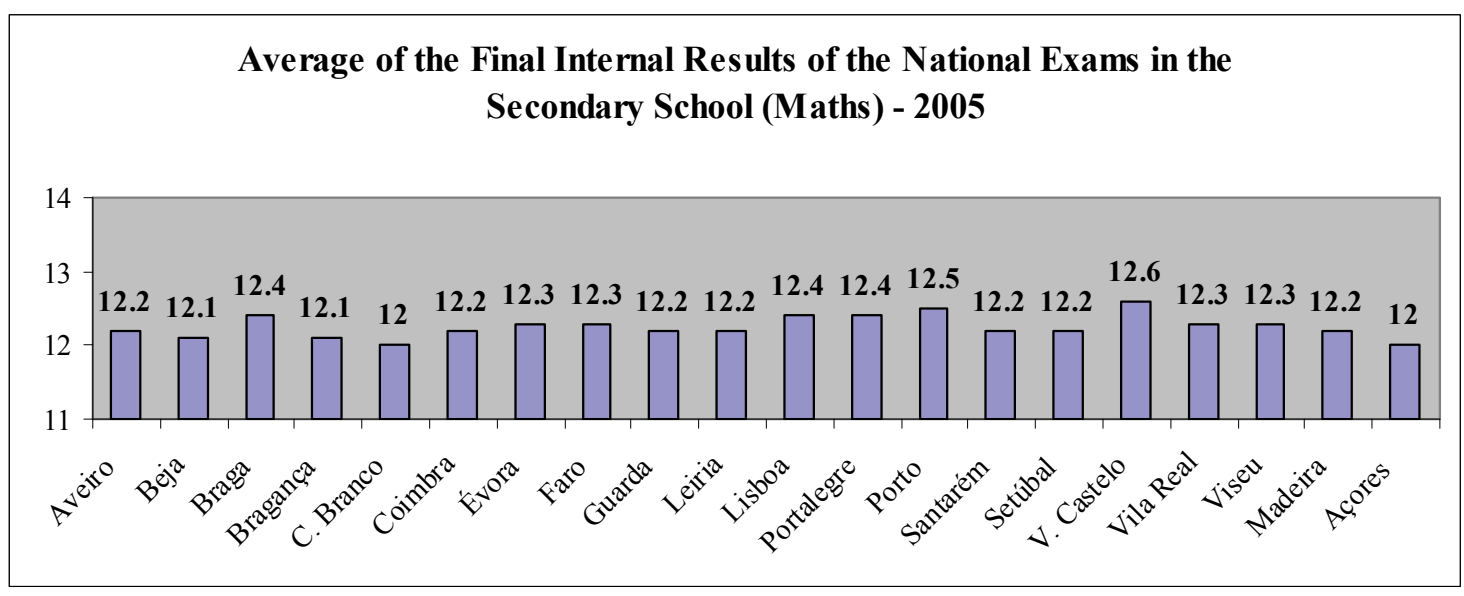

Figure 1 - Average of results in the National Maths Exam - 2005 (grades: 0 to 20) Based on "Júri Nacional de Exames, 2006"

The highest average, 85,1, was registered in Lisbon, which is far from being a positive result. Then, and talking about exam results, it comes Coimbra with 84,1, Leiria with 82,9, Braga with 80,0 , and the worst exam average was in Madeira Island, with 57,5.

The figures presented are obviously terrible results for students that are willing to apply for the University, and some of them are thinking about applying for a degree related to Mathematics.

The most curious thing about Mathematics is that students have good results all through the school year. Their final marks reflect the exam and the result they get after the $3^{\text {rd }}$ school term.

If the exams' results are low, it means that the students had a good mark at the end of the school year, otherwise their results would be lower than the ones presented in Figure 2. 


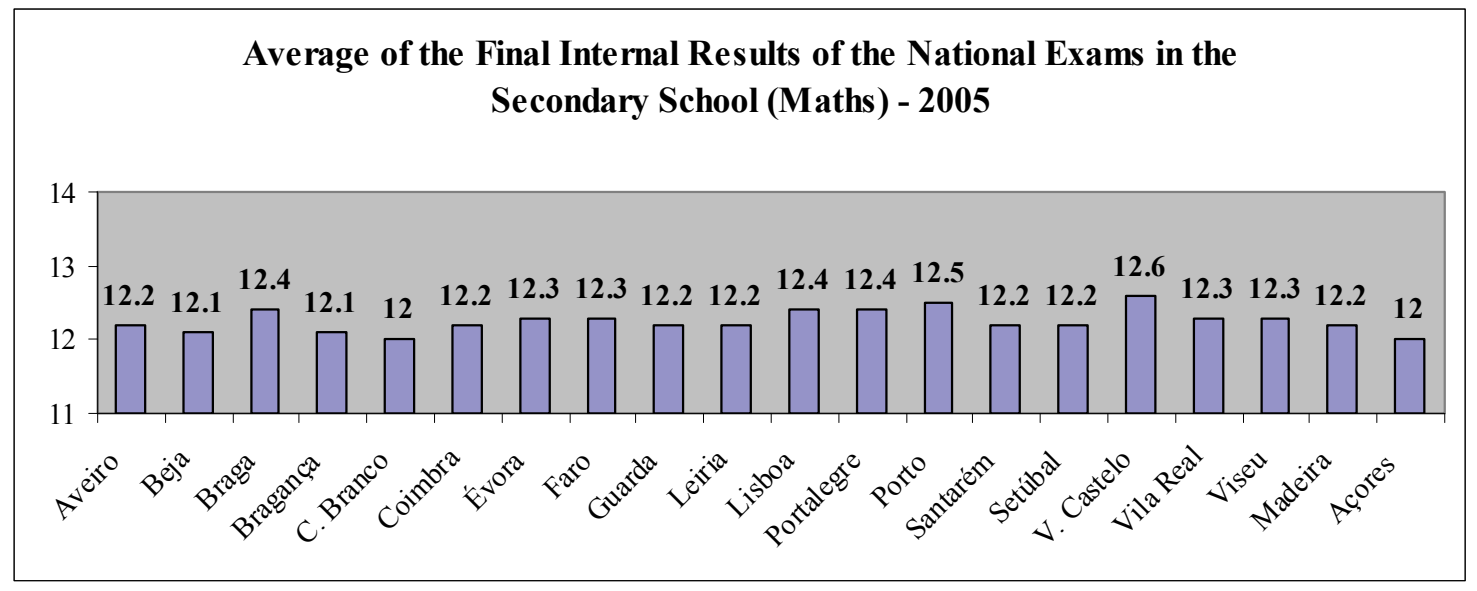

Figure 2 - Average of the Final Internal Results of the National Exams in the Secondary

School (Maths) - 2005 (grades: 0 to 20)

Based on "Júri Nacional de Exames, 2006"

As we can see, the averages of the final results are all positive, varying between 12 and 12,6. There's a slightly variation in the students' final results according to the different cities. This confirms the theory in which the teachers promote a teaching based on the explanation and practice of exercises, so that the students can give right answers on their tests.

The students' achievement in the national exams is, in fact, disastrous. In the past six years there were only negative averages. Even this year, 2006, the averages continue to be negative, which show that there's a continuous lack of success.

Table 1 -Results of the $12^{\text {th }}$ Form Maths Exams (grades: 0 to 20)

\begin{tabular}{|c|c|c|}
\hline & $1^{\text {st }}$ Phase & $2^{\text {nd }}$ Phase \\
\hline 2002 & 8,5 & 4,9 \\
\hline 2003 & 9,0 & 7,3 \\
\hline 2004 & 8,8 & 6,8 \\
\hline 2005 & 8,1 & 9,4 \\
\hline 2006 & 6,8 & 7,6 \\
\hline
\end{tabular}

Based on (www.exames.org/enes/notas/medias.php, 2006)

This reality, as easily seen in Table 1, is not a new question. In fact, it has been debated, when, after the involvement in international studies, the media draw the people's attention to the students' bad results in Mathematics.

Portugal has participated in the Project for International Student Assessment - PISA - promoted by OECD (Organization for Economic Cooperation and Development).

The major goal of this Project was to evaluate the essential skills that will allow students, who completed the compulsory education (until the $9^{\text {th }}$ form), to continue learning throughout life. These skills were evaluated in three different domains: Reading, Mathematics and Science.

Thus, the Project was organised in three stages: 
From 1998 to 2000 - Reading evaluation;

From 2001 to 2003 - Mathematics evaluation;

From 2004 to 2006 - Science evaluation.

This study counted with 41 countries, 30 of which were part of the OECD. In Portugal, 4608 students were evaluated. These students were from 153 different schools (12 private schools and 141 public schools) from all over the country (mainland and islands). The tests were given to 15 year old students, randomly chosen, just like the schools.

As this article is related to Mathematics, it will only be focusing the $2^{\text {nd }}$ stage of this Project.

When testing the students about Mathematics, the main goal was to test their Maths literacy. In other words, their ability to process the information they had on the subject and try to apply it to new situations, which were related to the real life.

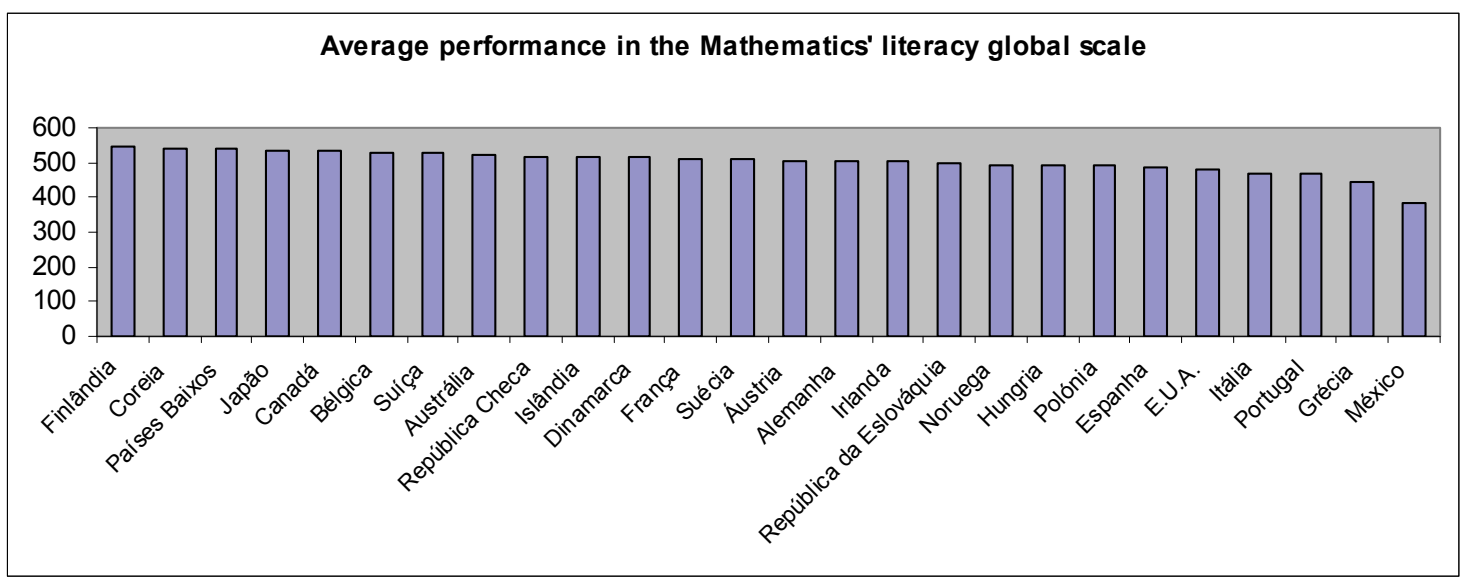

Figure 3: Global performance in Maths

Based on GAVE, 2004

Figure 3 clearly shows the Portuguese position when compared with the other OECD countries. Our students achieved the $24^{\text {th }}$ position after this study, with an average of 466 points. The difference, in terms of average, between the best country (Finland) and Portugal is 78 points.

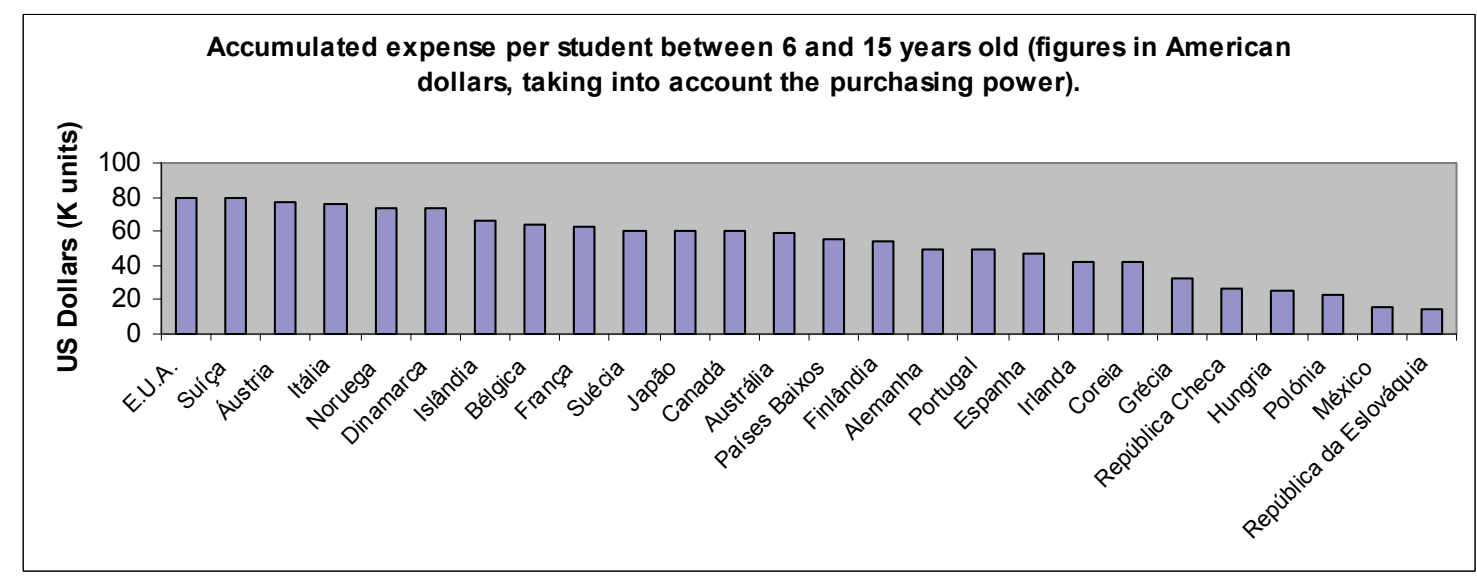

Figure 4: International Expense per Student Based on GAVE, 2004

Nevertheless, we may not assume teachers and students as the main reasons for this result, because, as it was initially mentioned, there are a lot of aspects that lead to it. One of them is the 
Portuguese Government contribution to Education, which is considered very low - 48811 dollars (see Figure 4). Therefore, our Educational system is a poor one, once the investment in schools isn't enough.

The low performances in the Mathematics' domain should be taken into account and changed. The unsuccess in Mathematics is notorious and this subject continues existing, once it was socially "conceived to lead to unsuccess. It results from the function given by the educational system and is recognized by everyone involved in the teaching/learning process. The truth is that Mathematics' major role is to contribute as a tool to the students' selection." (Ponte, 1994).

To sum up, in reality Portuguese students don't learn real mathematics' skills, and their weak results in the PISA Project, as well as in the national exams, can prove it.

It is important and urgent to change the Educational system in Portugal. The unsuccess in Mathematics can no longer be accepted and divulged. This subject is part of almost every school course, which may mean two things: first, many students need to have a good mark on Mathematics so that they can apply for the University; second, this subject is extremely important for a future job/profession connected with this science.

Mathematics is a true source of contribution to the children and younger people's growth, giving them the opportunity to develop a way of thinking that will be important for them as citizens and as part of the society. It can help them, for example, when they are buying/selling something, once they have to pay or give some change, or students may even use Mathematics' language to solve harder life situations.

However, the truth is that Mathematics is considered, by many, to be a very difficult subject, condemned to failure.

In Portugal, Mathematics' teaching is in crisis, because the way this subject is taught by teachers and seen by students is causing undesirable effects, which have been observed all through the years.

\section{Some of the Reasons for the Unsuccess in Mathematics}

When identifying the causes of unsuccess in Mathematics, one has to consider the four mediators of the educational system, although some have direct participation and others indirect. Students, teachers and the Ministry of Education are directly involved, but parents and society, in general, may have an indirect involvement.

\section{Teachers}

The teacher is an essential mediator when it comes to the Mathematics' teaching. He has the leading role in the classroom and he chooses the teaching strategies. However, most teachers tend to work with:

a) a mechanic teaching method, in which he systematises the subject's contents, followed by exercises;

b) poor teaching/learning strategies. This means that the teacher explains the subject's contents, orally or using the blackboard, followed by exercises (usually from the school book). In short, the teaching methods are poor and few.

c) Mathematics that is not applied to real life. Usually, this subject is taught through formulas and techniques so that students may solve exercises correctly. Still, they don't really understand the true value, essence and importance of the things they're learning. 


\section{Students}

The student is the main mediator in the teaching/learning process, once he's the one who has to study/work in order to succeed and improve skills. If, on one hand, the student shouldn't interfere in the way the teacher teaches, on the other he's expected to participate and ask questions, so that he understands the complete lesson. Though, the majority of students reveal:

a) lack of interest about school matters (in general) and the Mathematics (in particular). Many students think they won't get a positive result in Mathematics, so they don't even try to understand what the teacher is teaching. Sometimes, the way Mathematics is taught also worsens this situation;

b) lack of study habits. Most students don't have study habits, or study less then they should, and don't try to understand the contents they learn. In fact, students show they aren't much concerned about not having a positive result in Mathematics;

c) they're not critic and curious. In general, students accept the information transmitted by the teachers, without questioning its utility and without trying to know a little bit more about it;

d) lack of educational goals. Some students don't expect anything from school, which makes them bad learners. It is also true that most students don't like to go to school, and, sometimes, they skip classes.

\section{Ministry of Education}

The Ministry of Education is in charge of all educational system, being the responsible of the Education in Portugal. Consequently, it has part of the responsibility for the unsuccess in Mathematics. This is due to:

a) the poor subject's contents defined by this Ministry. In Portugal, there's a lack of important and useful teaching contents, which has drawn, in the last years, people's attention to the students' negative results. In order to fight these results, the Ministry of Education is being reducing the contents of this subject;

b) the Ministry of Education's pressure over teachers, so they approve students. In order to hide the students' failure, the Ministry restricted the number of subjects a student cannot succeed in a year. However, teachers are pressured to approve them, so that there isn't a high percentage of students failing the year;

c) the number of hours a student has to attend Mathematics' class per week, which isn't enough to teach all the subject's programme established by the Ministry of Education. Specially, because students don't understand Mathematics, and if teachers don't have more time, the students won't be able to follow the class's rhythm;

d) the lack of resources, materials and specific instruments in schools, such as software, games and computers with Internet connection to be used during classes.

\section{Parents}

Parents are not directly linked with the students' unsuccess in Mathematics. Nevertheless, it is indirectly connected with it, once:

a) there's a sort of parents' resignation. In other words, parents do not criticize their children for this failure, but they don't help them properly during their school life.

It seems correct to say that it's not only one of these mediators to hold responsibility for the unsuccess in Mathematics. In fact, all of them contributed to it. Therefore, the fight against this failure is harder, once it demands changes at different levels. 
The truth is that Education needs a revolution. The society has been developing itself, but Education hasn't. Our schools didn't follow the technological evolution, and one of the main changes is related to the use of informatics' equipment and resources.

Our society is focusing on information and communication, going along with the technological development, and Education's main goal should be to prepare students for this kind of society.

The concept of school education should no longer be a collection of skills (said to be essential) taught to students by the teacher in a classroom. This is not a desired situation. The most important is to help students to improve their capacity to develop their own skills.

\section{Possible Solutions for the Unsuccess}

The school has to support the society of knowledge. We don't expect the school to be the place where information is transmitted, but a place where students are prepared for a digital epoch, acquiring and/or developing skills, critic sense, creation and motivation to help them learning.

The school's major goal is to prepare people for the digital epoch, which implies a revolution in the way teaching is performed. The teaching/learning process will have to be supported by four pillars: learn to know; learn to do; learn to live with others; learn to be.

At this point, it's clear that to solve the unsuccess, there will have to be great changes in the Educational system at different levels. The Mathematics' teaching/learning strategies will have to be based on the technologies of information and communication, so that students feel motivated. In order to do that, the Ministry of Education must provide the necessary equipment to schools, so it can be used in the classroom.

As the use of Technologies in the teaching/learning process is supported, the rest of the article will be focusing the e-learning.

In short, strategies adopted by schools and teachers are failing and it cannot continue to be ignored.

Therefore, some of the motivations to use e-learning are directly connected with the pedagogical process are:

- to prevent the unsuccess and the school-leavers;

- to make school more interesting and appealing;

- to match the students' individual expectations;

- to respect each student's rhythm;

- to satisfy the students' curiosity on different knowledge areas;

- to keep the school updated;

- to develop capacities and skills, such as research/investigation, an active attitude, and ability to solve problems that may come through life.

More reasons could be pointed out, such as the fact that, nowadays, the World itself goes around the Internet. E-learning makes it easy for students to learn how to deal with a virtual environment, creating new spaces for learning.

Flexibility is another motivation, which can be analysed in different ways. Students may stay at home and have access to information almost everywhere and at all times. Those who learn easily may develop their skills and search for simultaneously information, while exchanging opinions with people from all over the world. 
E-learning can promote a richer, more motivating, stimulating, interactive, cooperating and flexible environment, in which you communicate rapidly and learn fast.

Some teachers only use e-learning. However, it seems that this will be the future of Education, once this methodology may be seen as an alternative to the traditional learning, making it more interesting and appealing.

This kind of methodology challenges the students' creativity, investigation and interaction, once they help each other, starting a strong teamwork, and a great interaction between students and students and teacher.

It would be very interesting for students to attend the lessons through the Internet. To illustrate this, there's an example which was applied in a lesson about the Pythagoras' Theorem.

The student gains access to the website, follows the Theorem demonstrations, understands them almost instinctively, and then he may test his knowledge.

During the next paragraphs it will be demonstrated the way teachers and students may access to e-learning websites. It will also be explained how these tools may be used in Mathematics' teaching.

So, the first step is to gain access to the platform, through the Internet:

http://quizstar.4teachers.org/

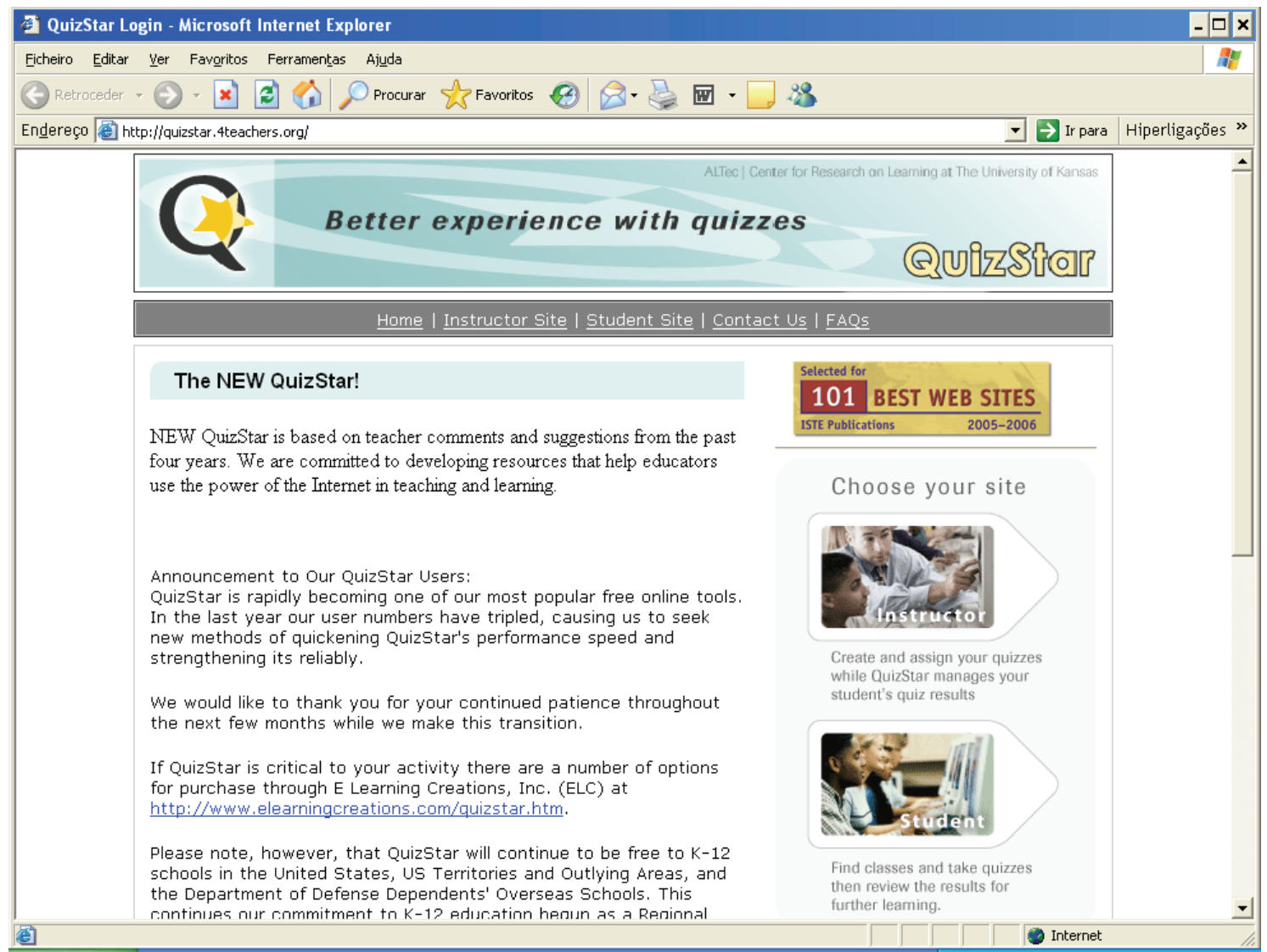




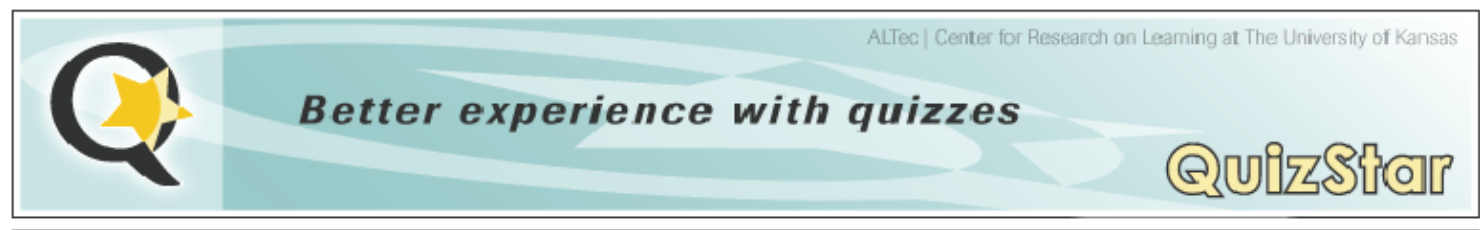

Home I Instructor Site I Student Site I Contact Us I FAQs

\section{The NEW QuizStar!}

NEW QuizStar is based on teacher comments and suggestions from the past four years. We are committed to developing resources that help educators use the power of the Internet in teaching and learning.

Announcement to Our QuizStar Users:

QuizStar is rapidly becoming one of our most popular free online tools. In the last year our user numbers have tripled, causing us to seek new methods of quickening QuizStar's performance speed and strengthening its reliably.

We would like to thank you for your continued patience throughout the next few months while we make this transition.

If QuizStar is critical to your activity there are a number of options for purchase through E Learning Creations, Inc. (ELC) at http://www.elearningcreations.com/quizstar.htm.

Please note, however, that QuizStar will continue to be free to $K-12$ schools in the United States, US Territories and Outlying Areas, and the Department of Defense Dependents' Overseas Schools. This

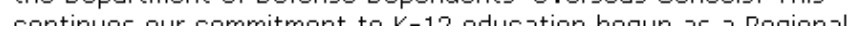

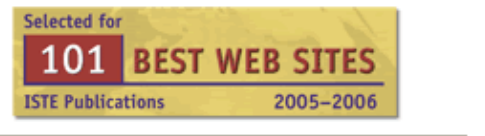

Choose your site

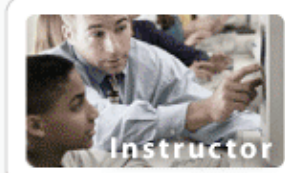

Create and assign your quizzes while QuizStar manages your student's quiz results

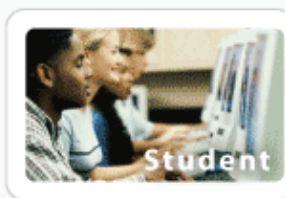

Find classes and take quizzes then review the results for further learning.

In order to have access to the content of each section, the new user has to make a registration before being allowed to login. This registration consists in filling in a form, where the user has to write the name and e-mail, to choose a username and a password, among other things. In the example presented, the user has to select whether he is a student or a teacher in order to make the login, as it can be seen in the screen picture below (in this case, the login is for a teacher). 


\section{E-Learning in the School}

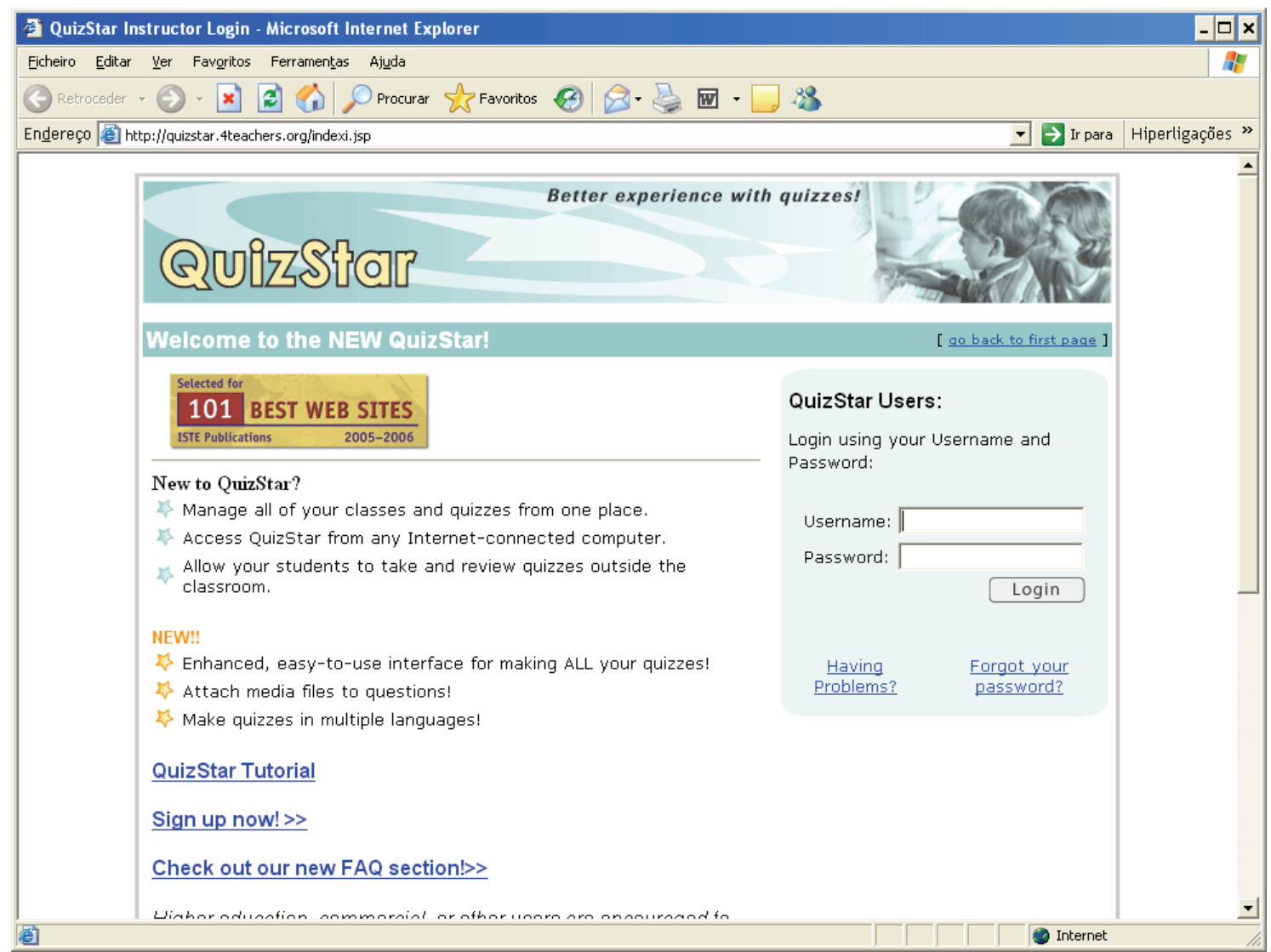

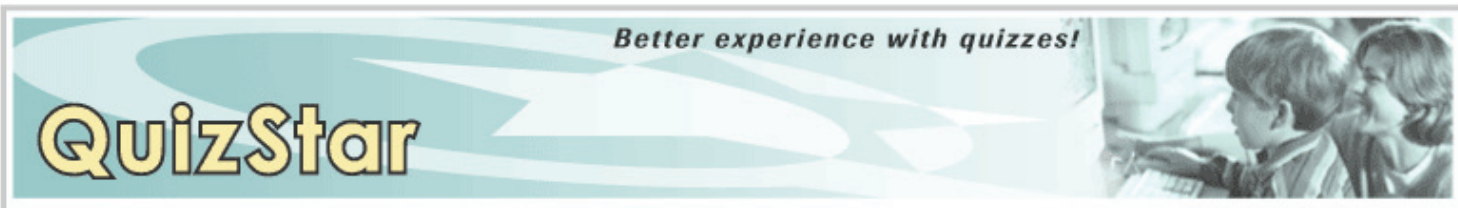

\section{Welcome to the NEW QuizStar!}

\section{[ go back to first paqe ]}

\section{BEST WEB SITES}

ISTE Publications 2005-2006

New to QuizStar?

7 Manage all of your classes and quizzes from one place.

4 Access QuizStar from any Internet-connected computer.

2) Allow your students to take and review quizzes outside the classroom.

NEW!!

\$ Enhanced, easy-to-use interface for making ALL your quizzes!

i) Attach media files to questions!

\& Make quizzes in multiple languages!

\section{QuizStar Tutorial}

Sign up now! \>

\section{Check out our new FAQ section!>>}

\section{QuizStar Users:}

Login using your Username and Password:

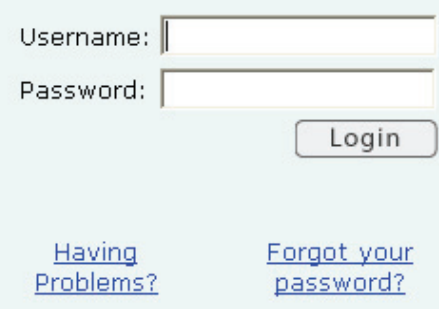


If the teacher is already registered in the website, he can continue with the login. However, if this is not the case, the teacher will have the opportunity to register by clicking with the mouse on Sign up now!, being redirected to the following page:
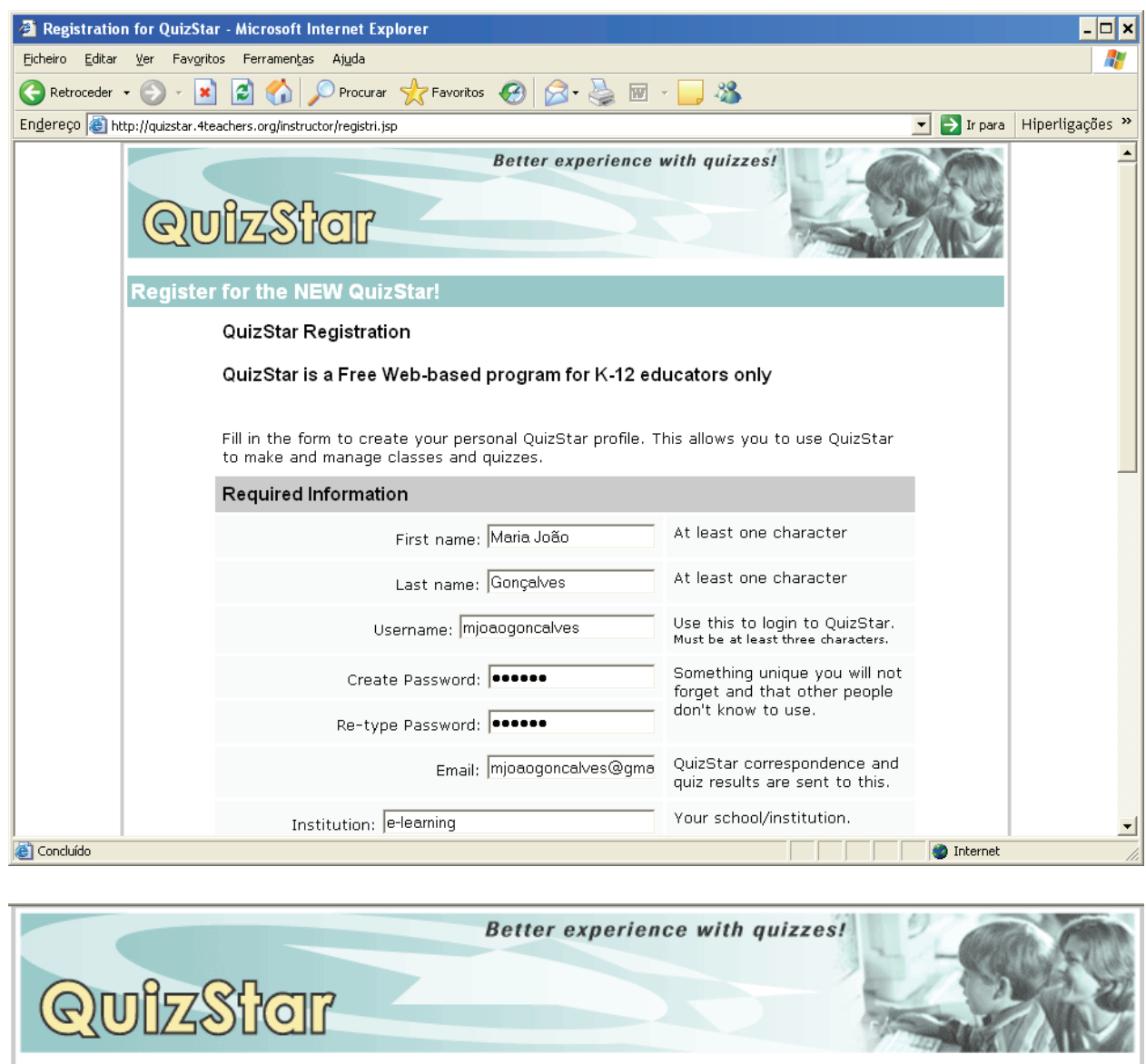

\section{Register for the NaW Quizstar:}

QuizStar Registration

QuizStar is a Free Web-based program for K-12 educators only

Fill in the form to create your personal QuizStar profile. This allows you to use QuizStar to make and manage classes and quizzes.

\begin{tabular}{|c|c|}
\hline \multicolumn{2}{|l|}{ Required Information } \\
\hline First name: Maria João & At least one character \\
\hline Last name: Gonçalves & At least one character \\
\hline Username: mjoaogoncalves & $\begin{array}{l}\text { Use this to login to QuizStar. } \\
\text { Must be at least three characters. }\end{array}$ \\
\hline Create Password: $\bullet \bullet \bullet \bullet \bullet$ & $\begin{array}{l}\text { Something unique you will not } \\
\text { forget and that other people }\end{array}$ \\
\hline Re-type Password: $\bullet \bullet \bullet \bullet$ & \\
\hline Email: $\longdiv { \text { mjoaogoncalves@gma } }$ & $\begin{array}{l}\text { QuizStar correspondence and } \\
\text { quiz results are sent to this. }\end{array}$ \\
\hline Institution: e-learning & Your school/institution. \\
\hline
\end{tabular}

After filling in the form with personal data, the teacher confirms the registration. If this is done successfully, the teacher will be automatically logged in. 


\section{E-Learning in the School}

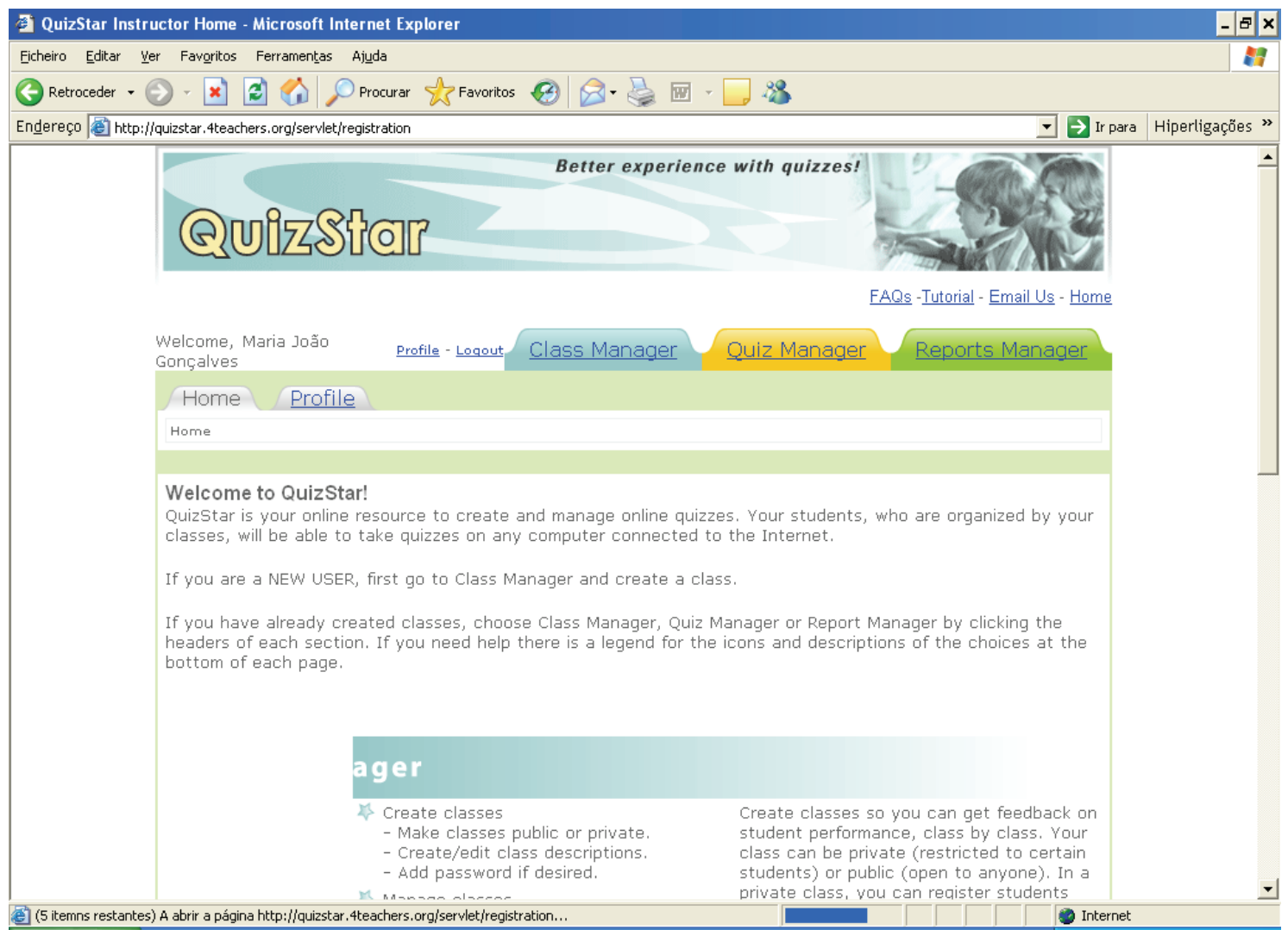

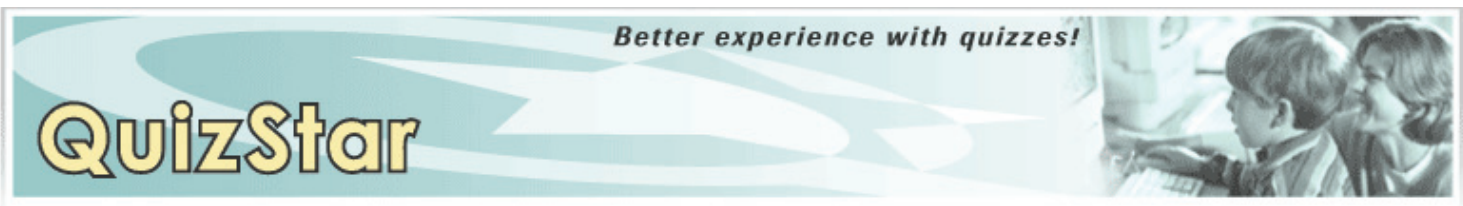

FAQs -Tutorial - Email Us - Home

Welcome, Maria Joấo Profile - Logout Class Manager Quiz Manager Reports Manager
Gonçalves
Home Profile
Home
Welcome to QuizStar!
QuizStar is your online resource to create and manage online quizzes. Your students, who are organized by your
classes, will be able to take quizzes on any computer connected to the Internet.
If you are a NEW uSER, first go to Class Manager and create a class.
If you have already created classes, choose Class Manager, Quiz Manager or Report Manager by clicking the
headers of each section. If you need help there is a legend for the icons and descriptions of the choices at the
bottom of each page.

In future visits to this website, teachers will only have to do the login in order to have access to its contents. 


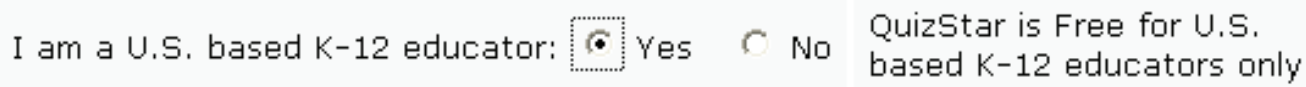

Concerning the students, the procedures are similar. In other words, they have to make the registration, so that they can have access to the login page.

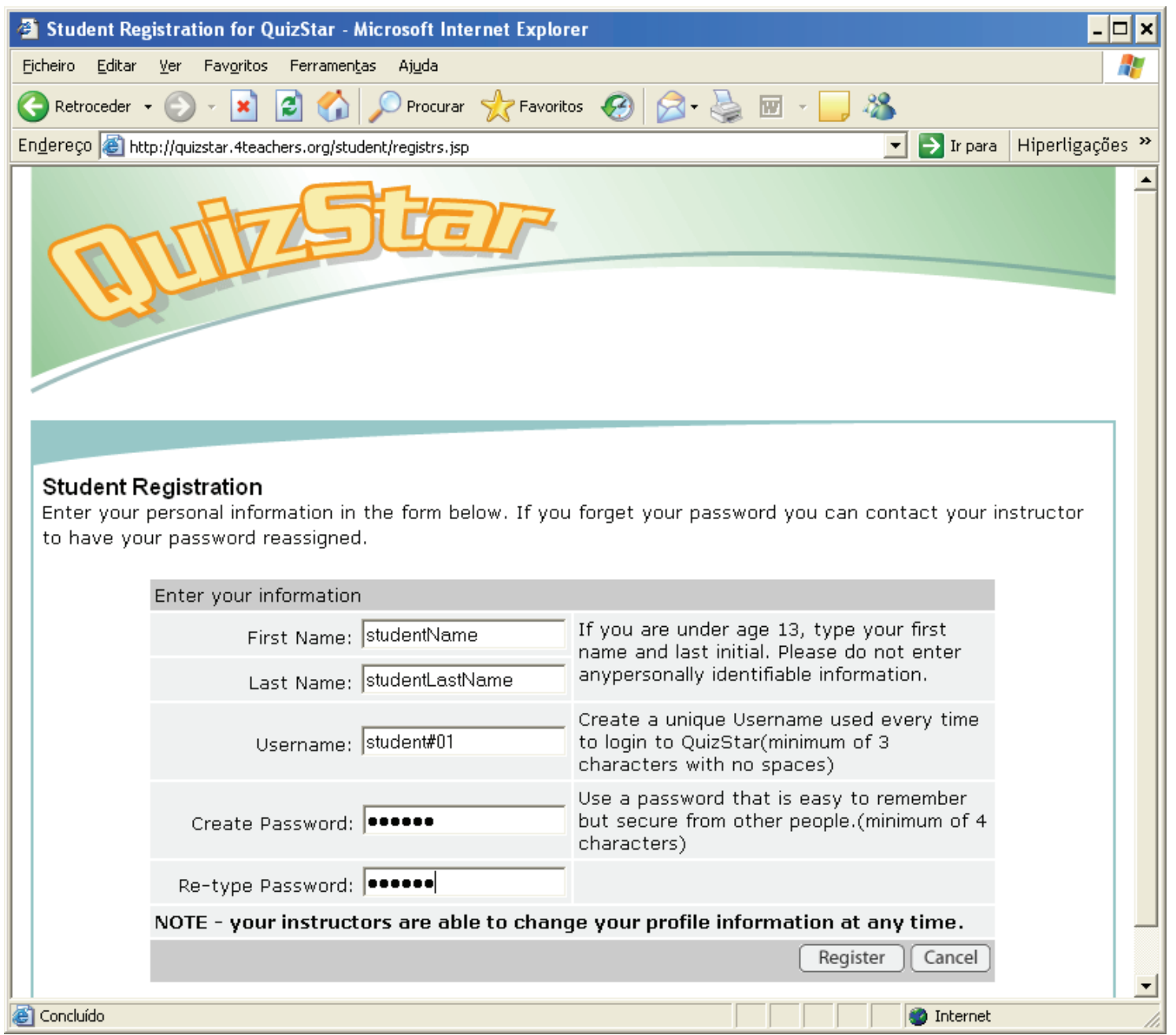




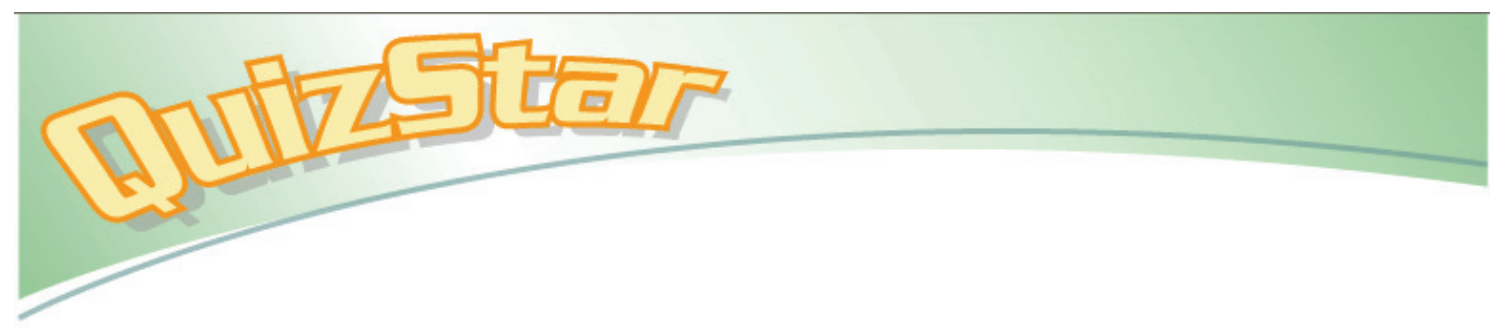

\section{Student Registration}

Enter your personal information in the form below. If you forget your password you can contact your instructor to have your password reassigned.

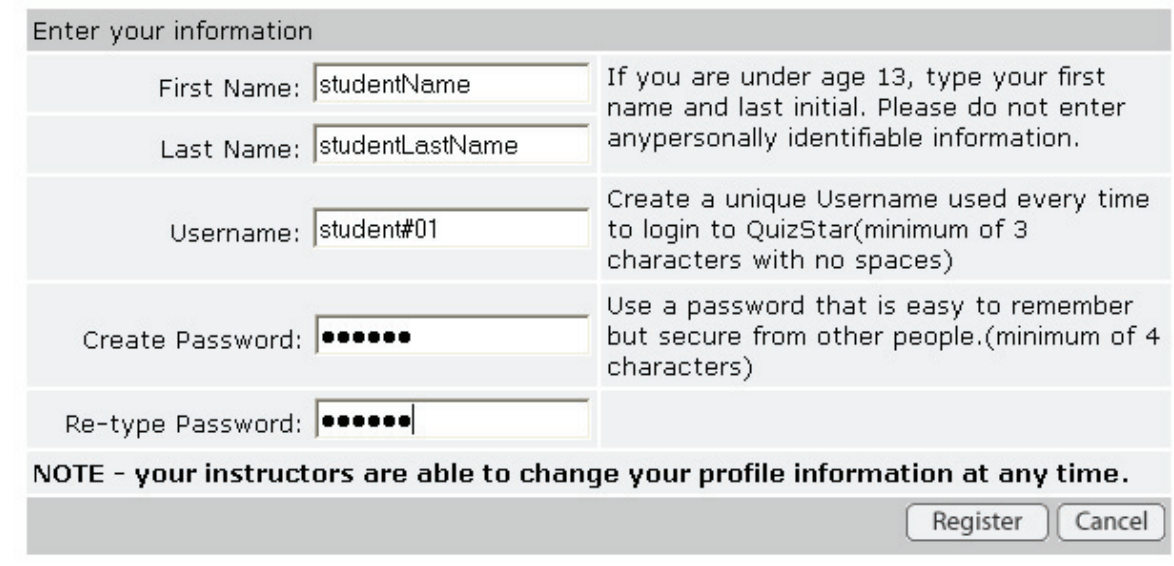

The teacher's field is divided in three different sections: Class Manager, Quiz Manager and Report Manager. These allow the teacher to create, manage and delete classes, to create and assign new quizzes, and to view the students' performance on quizzes. 

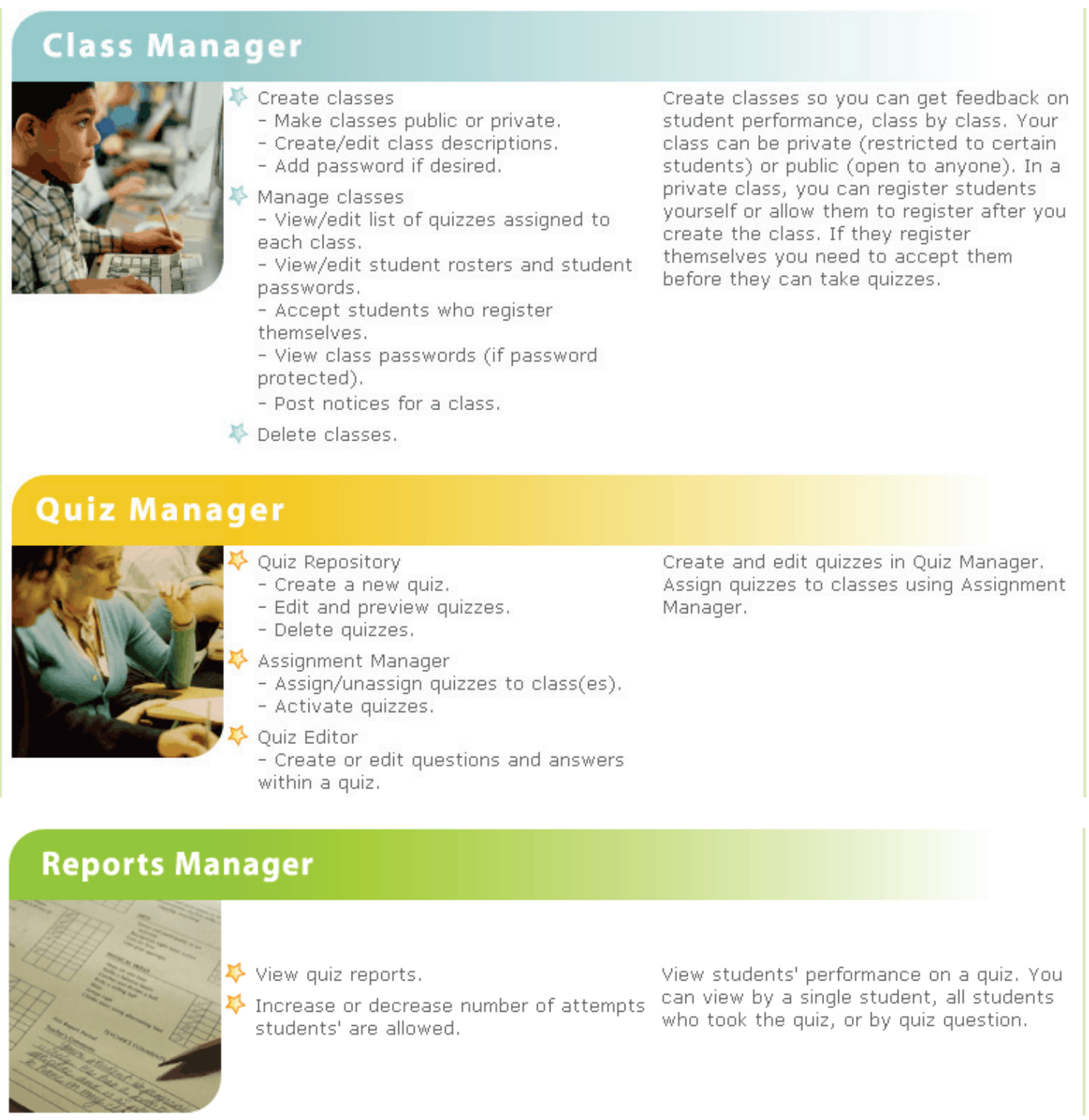

Afterwards, the teacher is redirected to a new page where different steps to create a class (e-class) are presented. To do so, he'll have to click on Create a New Class presented in the Class Manager section, as shown below: 


\section{E-Learning in the School}

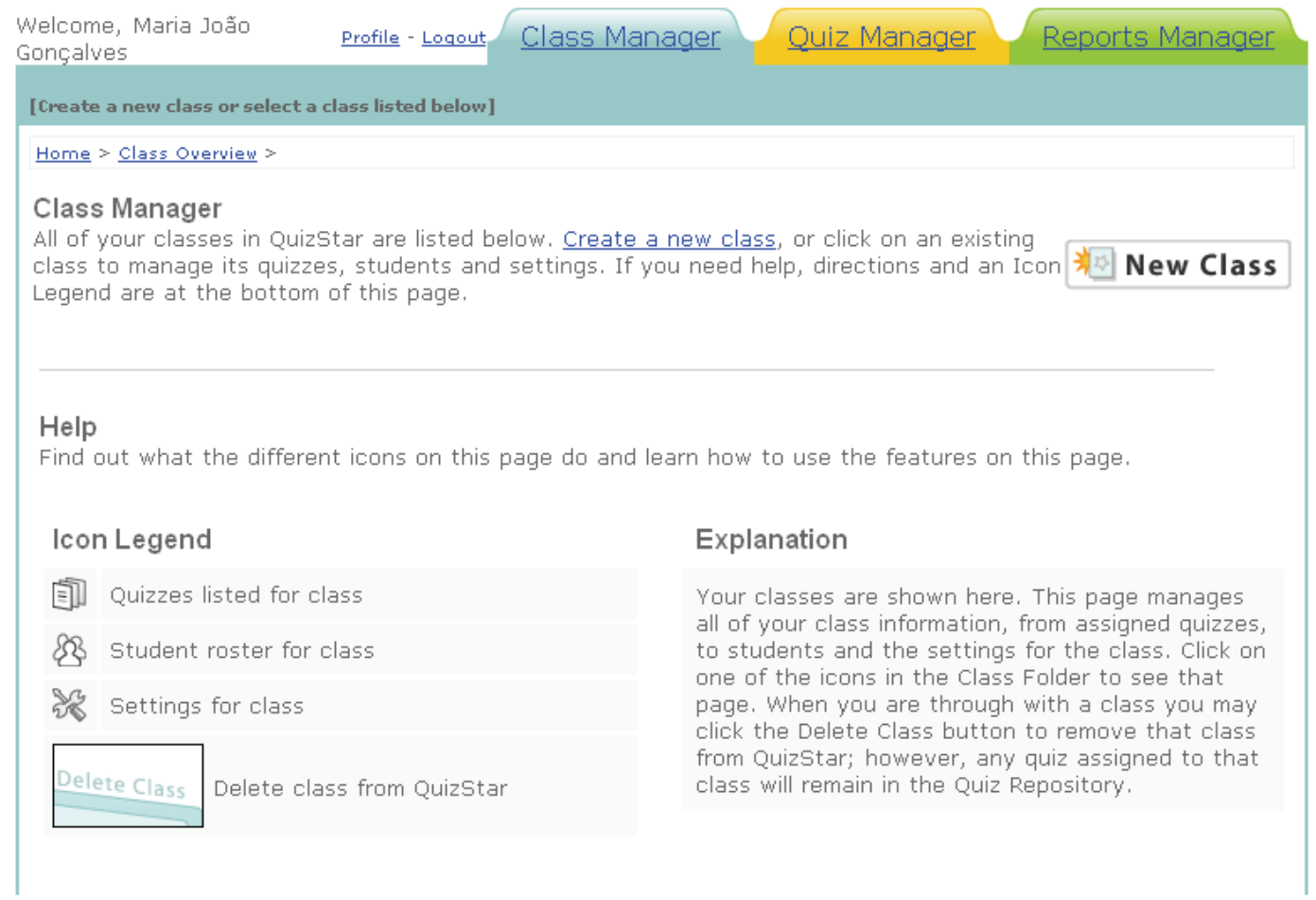

To create the class it's necessary to fill in the fields indicated, as shown next.

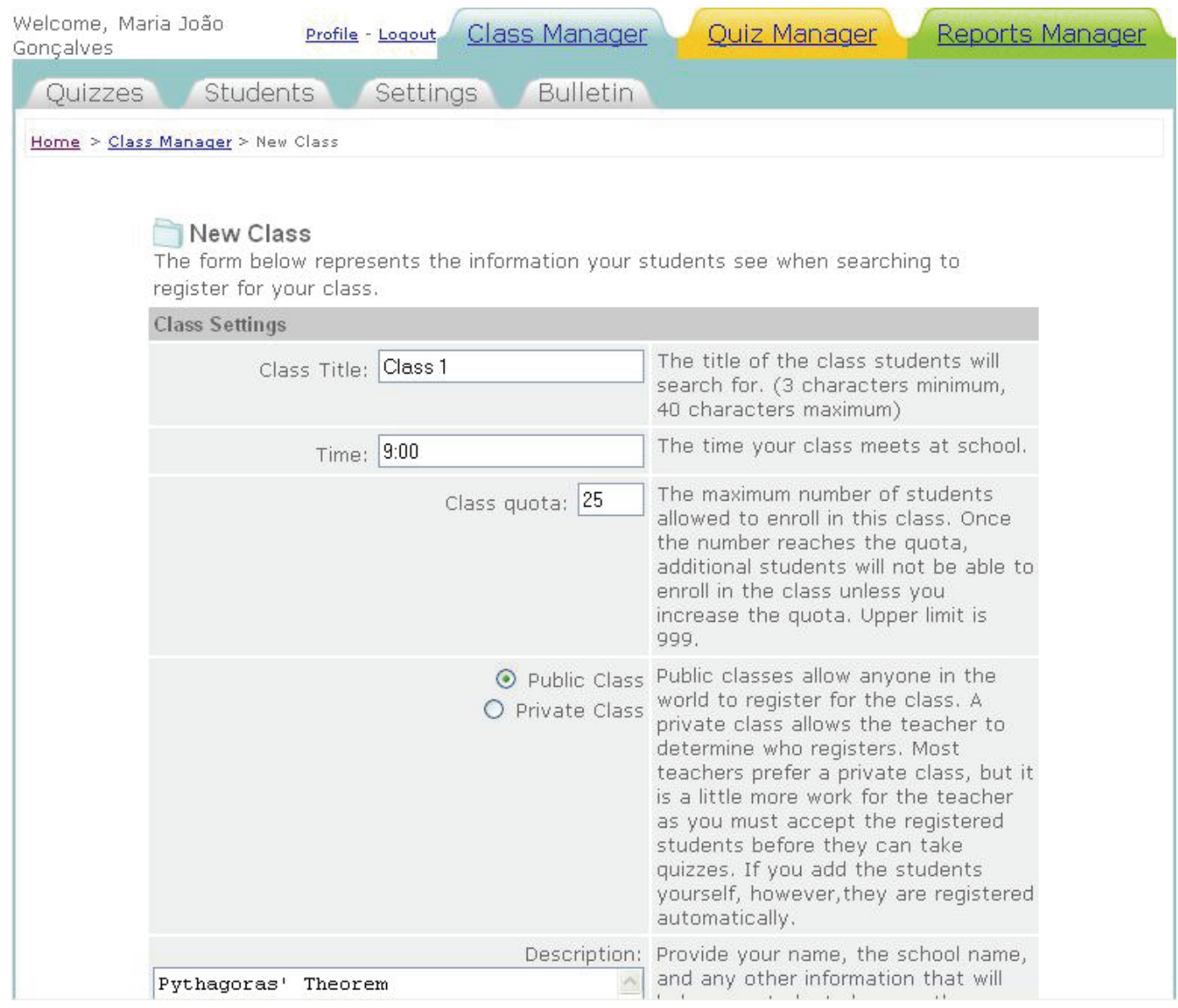


The teacher can create different classes for different contents and themes, as well as to suit the different educational needs of the students.

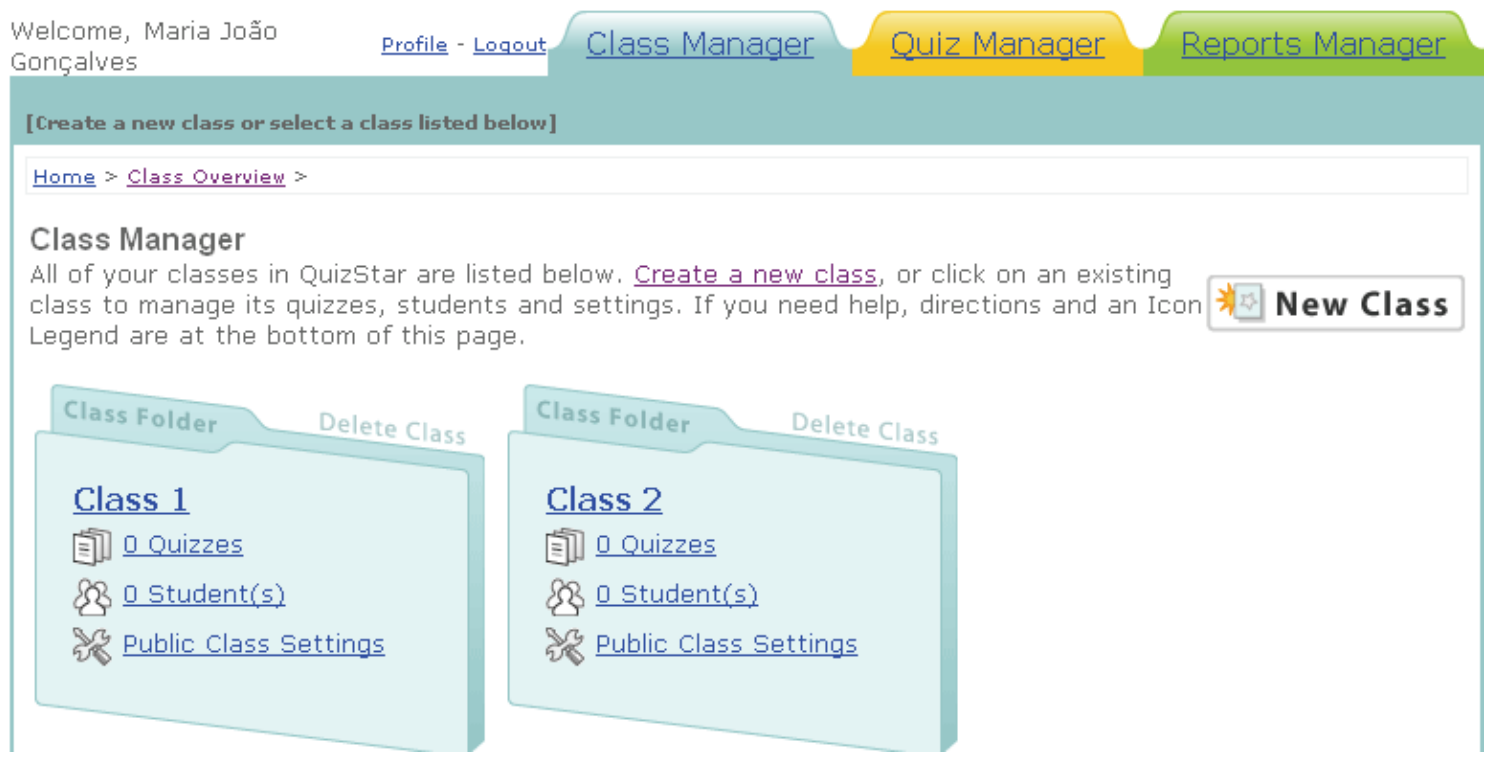

The contents addition (demonstrations, exercises and/or explanations) is made in the Quiz Repository from the Quiz Manager section. This appears as a logic step after creating a class.

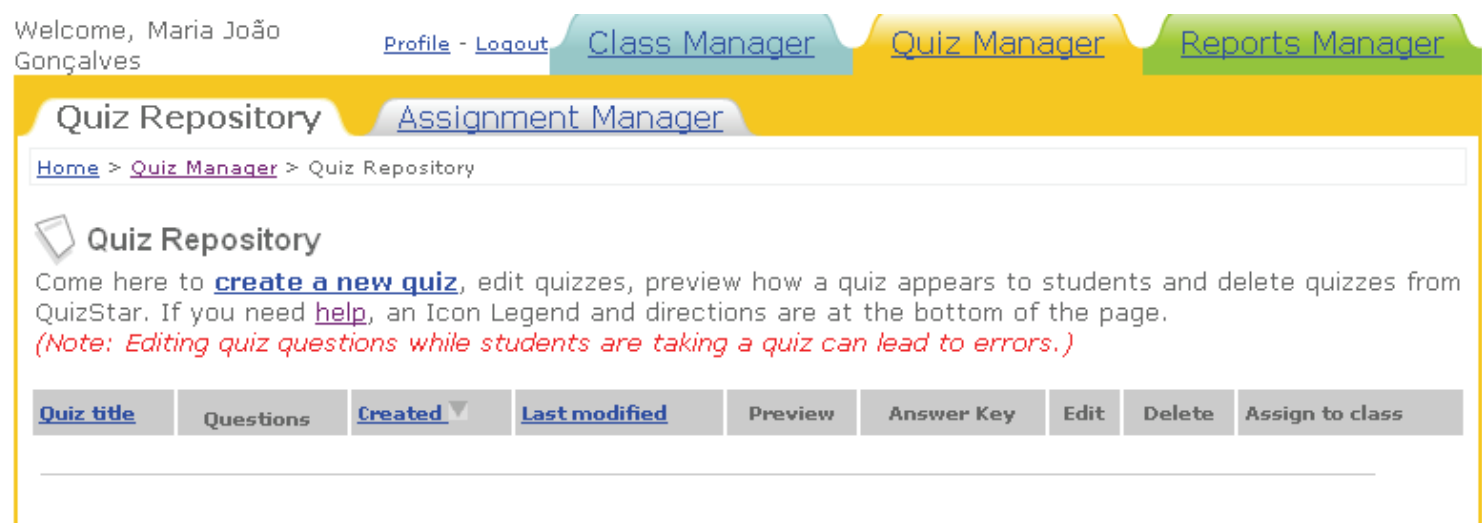

In order to explore and demonstrate the use of this e-learning website as a mechanism to help teaching, it will be presented an example with Pythagoras' Theorem.

In the next screen picture, it is clear to see the result of the contents addiction (Pythagoras' Theorem demonstration), as well as some exercises. 


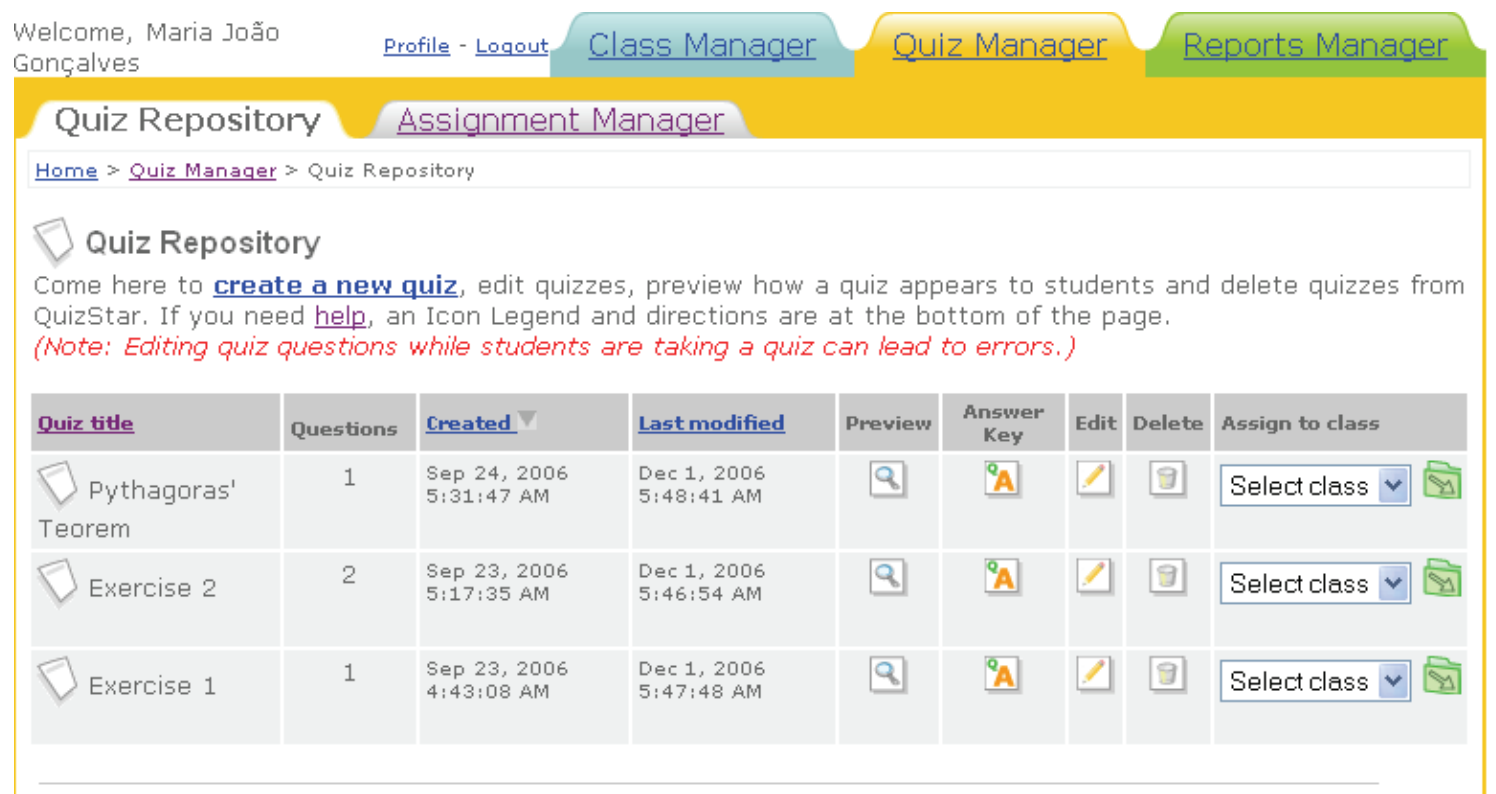

The next step will be the quiz assignment to the classes previously created, possible to do in the Assign to Class (which can be select in the menu previously presented). The details of each quiz, such as the start date and the finish date, are given in the following screen picture.

Welcome, Maria João Gonçalves

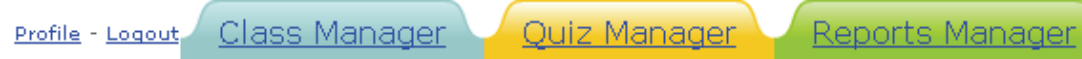

\section{Quiz Repository Assignment Manager}

Home > Quiz Manager > Quiz Assignment > Quiz Dates > Class 1

\section{Quiz Assignment Dates}

Set the dates the quiz is to be available to students. It will become available on the start date at the time you specify and will become unavailable on the finish date at the time you specify. Students cannot take a quiz after the specified finish time unless you change the finish date/time.

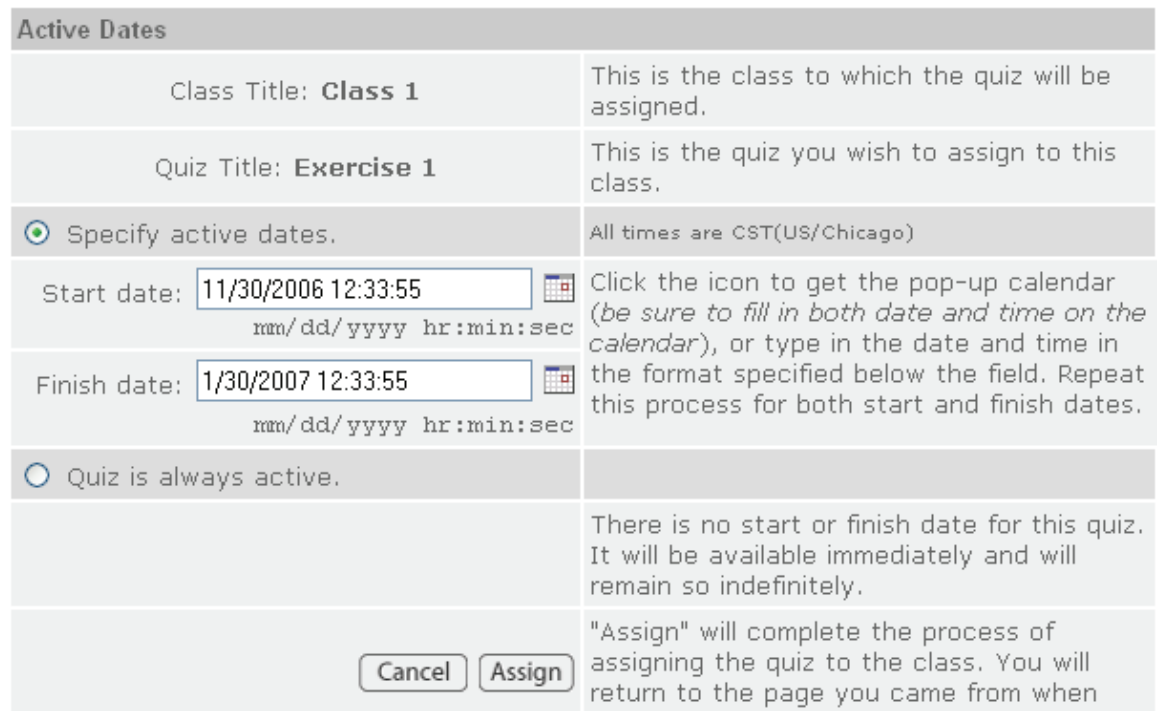


The Assignment Manager, in the Quiz Manager section, helps the teacher to manage all the quizzes assigned to classes, as displayed in the next screen picture.

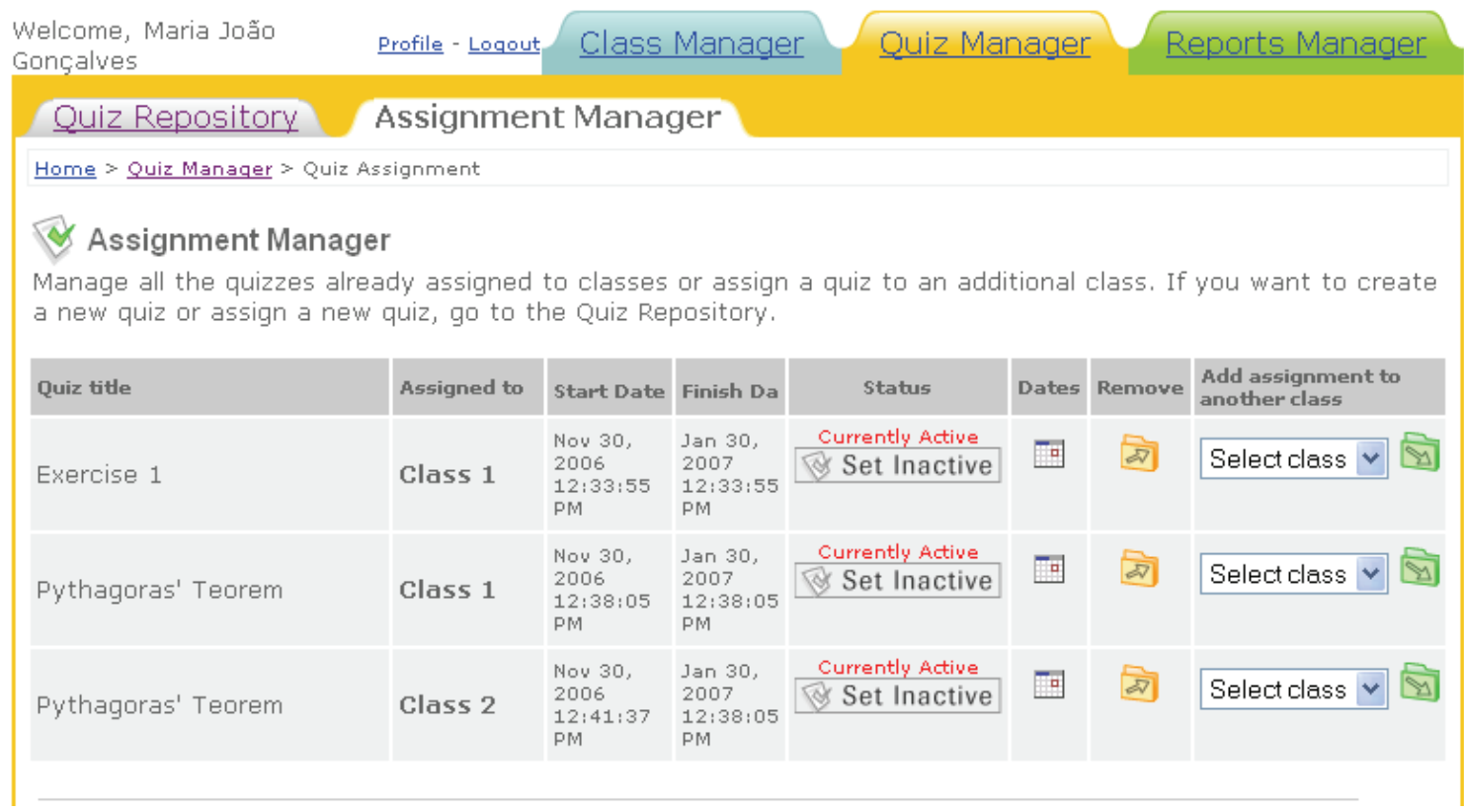

A class is defined as a group of students and, in this website case, the register in a class can be done by the student or the teacher. In the student's case, he will be able to register himself in the class he wants, searching in the website for the name of the class or for the name of the teacher. The screen image below presents the result of a search made by the name of the class.

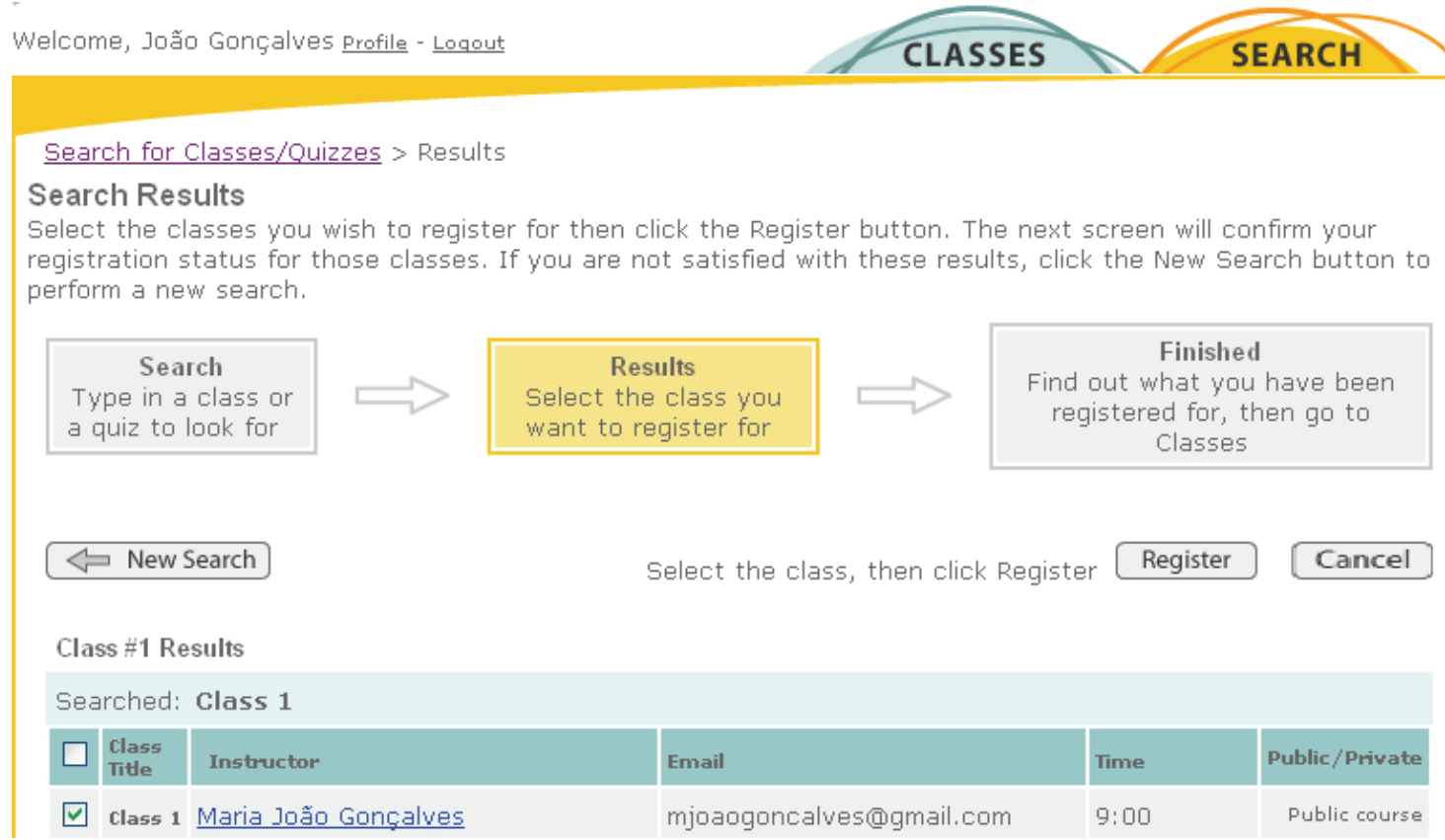

The student's registration will be completed after the class selection. 
However, if the teacher believes that some students have to make part of a specific class, he may register them in the Class Manager section.

Welcome, Maria João Profile - Logout Class Manager Quiz Manager
Gonçalves
Quizzes Students Settings Bulletin
Home > class Manaqer > class $2>$ students
Class 2's Students - Public Class
If your class is public, anyone can register and take your quizzes. If your class is
Private, only registered and accepted students can take the quizzes. Registration can
be handled two ways: 1) You register each student by clicking the Add Student
button. They are automatically accepted. 2) Students register themselves, then you
click the Accept Student button to add them to your class.

The teacher may also add a student to his class through his username.

\begin{tabular}{|c|c|c|c|}
\hline $\begin{array}{l}\text { Welcome, Maria João } \\
\text { Gonçalves }\end{array}$ & Profile - Logout Class Manager & \multicolumn{2}{|c|}{ Quizzes Students Settings Bulletin } \\
\hline \multicolumn{4}{|c|}{ Home $>$ Class Manager $>$ Class $2>$ Students $>$ Add Student } \\
\hline \multicolumn{4}{|c|}{$\begin{array}{l}\text { Add students to your class roster. You can either add students who have existing QuizStar accounts or you can } \\
\text { create a profile for the student yourself. If you want to create student profiles quickly, you can upload a Roster } \\
\text { (in CSV format) having the fields specified below. } \\
\text { (Please do not enter personally identifiable information for the student. You can enter the First Initial and Last name if you think it is not } \\
\text { personally identifiable. Most teachers make up names for their students.) }\end{array}$} \\
\hline & & Submit Cancel & \\
\hline & $\odot$ Registered QuizStar Stud & lent & \\
\hline & Username: & joaogoncalves & \\
\hline & Add New Student to Clas & s Roster & \\
\hline & First Name: & & \\
\hline
\end{tabular}

The search of a student through his username has given the following results. 


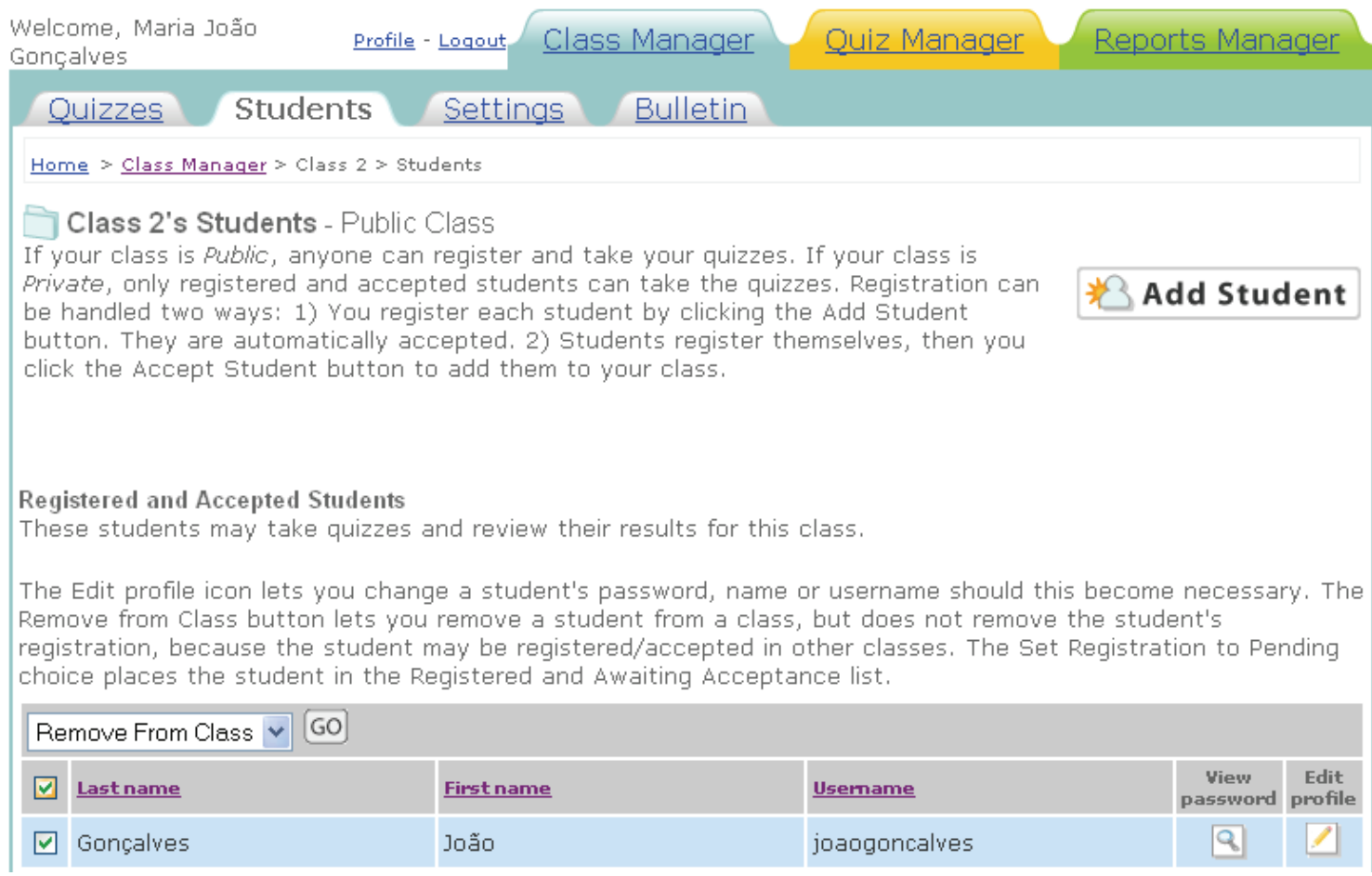

After adding a student to the class, this process will be concluded. This means that the teacher has all conditions, from an educational point of view, to start using this e-learning website with the students.

This example was created with the intention to continue using this e-learning tool. However, it is important to remember that each field and section has its own mechanisms, but in general, they all follow the steps described previously. 


\section{E-Learning in the School}

9 hittp:/quizstar.4teachers.org - QuizStar - Microsoft Internet Explorer

Close window

Last name, First name $\quad$ Course Name $\quad$ QuizStar

Directions:

1. Answer the questions below by dicking

the button next to the best answer choice

or typing your correct answer. Eat

2. At the end of every page click the next

button to move forward to the next pagt

BUTTON!

3. On the last page of the Quiz you will be ble to see which questions are unanswered, are answered and have been

1. Pythagoras' Teorem Demonstration

1 pts.

It is presumed that Pythagoras have made a demonstration like the one presented next.

The following rectangled triangle whose sides measure, in one given unit, $a$ and $b$, and the hypotenuse measures $c$.

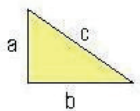

First draw two equal squares of sides $a+b$ :
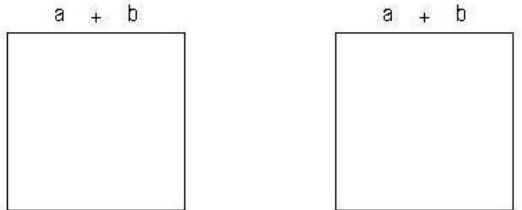

Second, in one of the squares draw 4 triangles in the following way

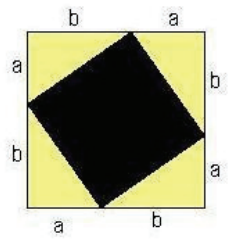

In the other one draw two squares and 4 triangles:

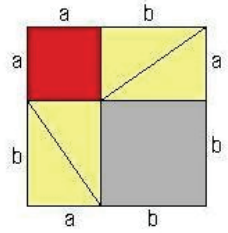

Theach figure the initial square has of side $a+b$. One of the squares was divided in 4 triangles and a square with side equals to $c$ (the rectangle triangle hypotenuse considered initially).

The other square was also divided in 4 equal triangles with size equal to the ones of the previous square.

However if we have two squares geometrically equals and both contain 4 geometrically equal triangles with the same measures of initial rectangled triangle, what remains in one square to be equal to what remains in the other.

Compare the areas of the squares that remain and we have:

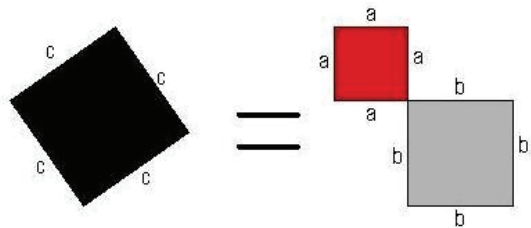

So we have:

$c^{2}=a^{2}+b^{2}$ 
The actual teaching standards are no longer sustainable. Therefore, the educational agents have an important role in the changes that will have to happen, since the informatics' resources are essential associates of the education, and there are numerous studies that can demonstrate it.

\section{Some Thoughts and Reflections}

The traditional education, in which the teacher transmits knowledge and the students only have to learn and to be evaluated by tests, has no longer positive results.

There's a clear necessity and urgency in changing the way people face the education/teaching and the strategies that make the information reach the students. However, it wouldn't be correct to unconditionally support the e-learning process, once we're dealing with a very delicate theme Education. We need to realize that when children first go to school they are 6 years old (in general). By the time they go to the Secondary School they are 15 years old, and they enter the University with 18 years old. This is to say that the age amplitude is large and, consequently, the students' maturity and responsibility is also different during their school course.

Therefore, e-learning may not be a good solution for all range of students (from the younger to the older), nor for all the problems that have been reported on education. Younger students don't have enough autonomy, knowledge and responsibility so that we can replace the traditional education for the e-learning process.

E-learning is only functional if people dedicate some time to work with it and if they have some personal abilities (such as auto discipline, critic sense, knowledge and determination) and technologic skills (basic concepts of informatics).

It is assumed that, until the $6^{\text {th }}$ form, students must be taught with the teacher's presence, although his methodologies may be based on new technologies. From the $7^{\text {th }}$ form, education can be, in fact, an alliance between the teacher's presence and the e-learning. From the moment the student goes forward to a superior course, he must show skills to undertake just an e-learning education.

To sum up, education is considered to be in the right track for success and that the e-learning process has all the potential to revolutionize the methodological strategies, leading to new ways of teaching/learning. At this moment, each teacher/educator should reflect on his methodologies and deliberate if, in fact, they have helped to form dynamic citizens, able to think and criticize, ready to live in a society where competition and proficiency are the main rules, and able to keep up with the technological evolution of our daily life.

\section{References}

Baptista, Carina (2004). Os desafios do e-learning em Portugal. In Cadernos e-learning: práticas de elearning em Portugal, seis workshops na universidade do Minho. Minho: Tec Minho/Gabinete de Formação Contínua.

Borràs; Laura. (2005). E-Learning and literary studies towards a new culture of teaching?. www.dichtungdigital.com

Cabrita, Isabel (1991). A problemática do Insucesso Educativo em Matemática no $3^{\circ}$ Ciclo do ensino Básico. Aveiro: Universidade de Aveiro.

Cação, Rosário; DIAS, Paulo Jorge (2003). Introdução ao e-learning. $1^{\text {a }}$ ed. Porto: Sociedade Portuguesa de Inovação.

Cação, Rosário (2003a). O e-learning como oportunidade de negócio. $1^{\mathrm{a} e d . ~ P o r t o: ~ S P I . ~}$

Comissão Das Comunidades Europeias (2000). Relatório da Comissão ao Conselho e ao Parlamento Europeu - Pensar o futuro da educação promover a inovação através das novas tecnologias. Bruxelas: Comissão das Comunidades Europeias. 
Costa, Carlos Carvalho da (2004). Educação matemática contra a malfadada iliteracia. Revista Correio Sindical. Coimbra. $\mathrm{N}^{\mathrm{o}} 52$, p. 7.

Dias, Ana Augusta Silva; GOMES, Maria João (coords.) (2004). e-learning para e-formadores. $1^{\text {a }}$ ed. Porto: Sociedade Portuguesa de Inovação.

Expressoonline (18 de Janeiro de 2004). Saiba tudo sobre e-learning! www.expressoemprego.clix.pt.

Fernandes, Carina Alexandra Araújo (2003). Projecto-piloto de e-learning numa instituição de ensino superior: a perspectiva dos pontos críticos. (tese de mestrado) Guimarães: Escola de Engenharia/Universidade do Minho.

Figueira, Mário (2003). O valor do e-learning. $1^{\text {a }}$ ed. Porto: Sociedade Portuguesa de Inovação.

Gave (2004). Resultados do Estudo Internacional PISA 2003. http://www.gave.pt/pisa/resultados pisa2003.pdf

INE (2002).Utilização das tecnologias de informação e comunicação pelas famílias - 2001. www.INE.pt.

INE (2003).Inquérito à utilização de tecnologias da informação e comunicação pelas famílias - 2003. www.INE.pt.

Juri Nacional De Exames (2005). Média das classificações dos exames nacionais. www.exames.org/enes/notas/medias.htm

Leria, Isabel (10 de Março de2003). Dados do abandono escolar. www.NetProf.pt.

Leiria, Isabel (2005). Média negativa na prova de Matemática desce pelo $3^{\circ}$ ano consecutivo. www.publico.clix.pt

McConnell, David (1994). Implementing computer supported cooperative learning. London: Kogan Page Limited.

M.C./R.P.L. (2004). Apenas onze distritos tiveram médias positivas. Jornal Expresso no 1666 de 2 de Outubro.

Ministério Da Educação; Ministério Da Segurança Social E Do Trabalho (2004). Eu não desisto: Plano Nacional de Prevenção do Abandono Escolar. Lisboa: Ministério da Educação/Ministério da Segurança Social e do Trabalho.

OCDE (2004). Education at a Glance. Paris: OCDE.

Pimenta, Pedro (2003). Processos de formação combinados. 1ªed. Porto: SPI.

Ponte, João Pedro (1988). Matemática, insucesso e mudança: problema possível, impossível ou indeterminado? Revista Aprender. Portalegre. Vol. VI, pp. 10 - 19.

Ponte; João Pedro da (1994). Matemática: Uma disciplina condenada ao insucesso? www. fc.ul.pt/docentes/jponte/docs.pt/94.

Ponte, João Pedro da; OLIVEIRA, Hélia (2000b). A internet como recurso para o ensino da Matemática. www. fc.ul.pt/docentes/jponte/docs.pt.

Ramalho, G. (2001). Resultados do estudo internacional Pisa 2000: Primeiro relatório nacional. Lisboa: Ministério da Educação/Gabinete de Avaliação Educacional (GAVE).

ROSA, Inácio (2005). Exames: Média Da Segunda Fase Subiu Em Relação Ao Ano Passado. Www.Publico.Clix.Pt.

Underwood, Jean D. M.; Underwood, Geoffrey (1995). Computers and Learning - Helping Children acquire thinking skills. $3^{\text {a }}$ ed. Oxford: Blackwall Publishers.

Wolfe, Christopher R. (2000). Learning and teaching on the world wide web. London: Academic Press. 


\section{Biographies}

Claus Kaldeich is a Professor of the Graduation Course of Computer Science for Management at the Department of Information Systems, University of Minho, Guimarães, Portugal and was an invited Professor of " $e$-Learning" and Advisor of Master Dissertations in the PostGraduation/Master Course of Education Management and Planning at the Department of History and Education Sciences, University Portucalense, Porto, Portugal. His PhD is in Applied Computer Science from the University of Karlsruhe, Germany.

Maria João Gonçalves has a Masters in Administration and Planning in Education, Department of History and Education Sciences, University Portucalense, Porto, Portugal. Her main research subjects are: Mathematics; E-learning; Information and Communication Technology (ICT). 